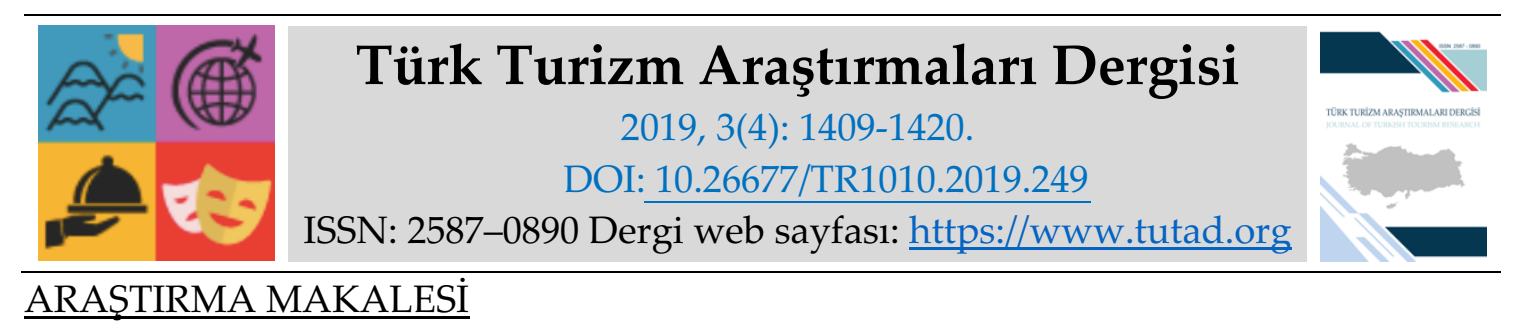

\title{
Kırsal Turizm Bölgelerinde Festivallerin Destinasyon İmajına Etkisi: Kuşadası Caferli Örneği*
}

Dr. Öğr. Üyesi Ahu Yazıcı AYYILDIZ, Adnan Menderes Üniversitesi, Turizm Fakültesi, Aydın, e-posta: ayazici@adu.edu.tr

ORCID: https://orcid.org/0000-0002-1301-2428

Özlem ESEN, Adnan Menderes Üniversitesi, Sosyal Bilimler Enstitüsü, Aydın, e-posta: ozlem.esen@outlook.com

ORCID: https://orcid.org/0000-0003-2539-7641

Dr. Öğr. Üyesi Tuğrul AYYILDIZ, Adnan Menderes Üniversitesi, Turizm Fakültesi, Aydın, e-posta: tugrulayyildiz@gmail.com

ORCID: https://orcid.org/0000-0001-6332-975X

Öz

Kırsal turizm bölgenin gelişimine önemli katkılar sağlayan, bölgedeki doğal ve kültürel kaynakları tanıtan, dünyada ve Türkiye'de giderek daha fazla ilgi görmeye başlayan turizm çeşitlerinden biridir. Deniz-kumgüneş üçlemesi dışında alternatif bir turizm çeşidi olması ve dört mevsim yapılabilmesi nedeniyle popüler hale gelmektedir. Turizm sadece ekonomik gelir kaynağı sağlayan bir endüstri değil aynı zamanda turistler ve toplumlar arasında sosyal ve kültürel alışverişi sağlayan bir köprü görevini de üstlendiğinden sosyal ve kültürel alışverişin sağlanması için düzenlenen festivaller, turistlerin bölgeyi tercih etmesini sağlayan önemli çekicilik unsuru olan etkinliklerdir. Kırsal turizm bölgelerinde gerçekleştirilen festivaller, farklı destinasyonlardan gelen katılımclarla bölgenin tanıtımına, ekonomisine ve kalkınmasına katkı sağlayarak, kültürel bütünleşmeyle birlikte destinasyon imajının gelişmesini desteklemektedirler. Çalışmanın amacı Aydın ili Kuşadası ilçesine bağlı Caferli'de düzenlenen festivallerin Caferli'nin imajına etkisini ortaya koymaktır. Çalışmada nitel araştırma tekniklerinden yarı yapılandırılmış görüşme tekniği kullanılmıştır. Bu amaçla Caferli'de bulunan yerel işletme sahipleriyle yüz yüze görüşmeler gerçekleştirilmiştir. Bu çalışma, festivallerin kırsal turizme olan etkisini ve destinasyon imajına katkısını değerlendirerek literatüre, bölgede yaşayan yerel işletme sahiplerine ve diğer paydaşlara yol gösterici olacaktır. Caferli'de senede iki defa olmak üzere düzenlenen Çiçek Festivali ve Güz, Çevre Festivali'nin bölgeye turist çekerek Caferli'nin kalkınmasına katkı sağladığı sonucuna ulaşılmışır.

*Bu çalışma 8. Ulusal ve III. Uluslararası Kırsal Turizm Kongresinde bildiri olarak sunulmuş ve özet olarak basılmıştır.

Anahtar Kelimeler: Caferli, Destinasyon İmajı, Festivaller, Kırsal Turizm.

Makale Gönderme Tarihi: 01.07.2019

Makale Kabul Tarihi: 04.10.2019

Önerilen Atıf:

Ayyıldız, A. Y., Esen, Ö. ve Ayyıldız, T. (2019). Kırsal Turizm Bölgelerinde Festivallerin Destinasyon İmajına Etkisi: Kuşadası Caferli Örneği, Türk Turizm Araştırmaları Dergisi, 3(4): 1409-1420.

(C) 2019 Türk Turizm Araştırmaları Dergisi. 


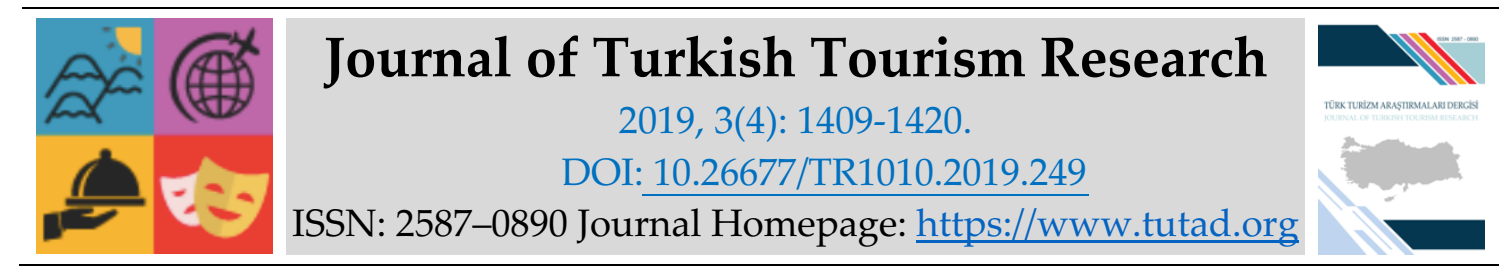

$\underline{\text { RESEARCH PAPER }}$

\title{
Festivals Effects on the Destination Image in Rural Tourism Regions: The Case of Kusadası Caferli
}

Assistant Prof. Dr. Ahu Yazıcı AYYILDIZ, Adnan Menderes University, Faculty of Tourism, Aydın, email:ayazici@adu.edu.tr ORCID: https://orcid.org/0000-0002-1301-2428

Özlem ESEN, Adnan Menderes University, Social Sciences Institute, Aydın, e-mail: ozlem.esen@outlook.com

ORCID: https://orcid.org/0000-0003-2539-7641

Assistant Prof. Dr. Tuğrul AYYILDIZ, Adnan Menderes University, Faculty of Tourism, Aydın, e-mail: tugrulayyildiz@gmail.com ORCID: https://orcid.org/0000-0001-6332-975X

\begin{abstract}
Rural tourism is one of the tourism types, which contributes region's improvement significantly and promotes natural and the cultural resources as well. It is one of the tourism types that is catching more attention increasingly in Turkey and in the World. It becomes popular thanks to its uniqueness and as it can be done in the four seasons of the year, in addition to that, it is an alternate tourism type, that is not consisted of sea-sand-sun trio. Tourism industry a bridge between tourists and civilizations in terms of social and cultural exchange. Tourism is not only an economic income source, but also it is a bridge that provides social and cultural exchange between the tourists and societies. These festivals, which are organized to provide social and cultural exchange, are important attractive reasons for the tourists to prefer the region. Aim of the study is to manifest the festivals' contribution to the Caferli's image, where is connected to Aydin province and Kuşadası district. Semi-structured interview technique, which is among the qualitative research technique, is used in this study. With this aim, interviews have been done with local business owners. Significance of this study is that, it will be a guide for the local business owners who are living in the region and for the other stakeholders by evaluating festivals' effects on rural tourism and contributes to the destination image. Results of this study present information about negative and positive effects on the destination image of festivals in rural tourism. Being as a rural tourism area, in Caferli, flower festival and fall- environment festivals are held twice in a year, which contributed to the Caferli's development by attracting tourists, is reached as a result.
\end{abstract}

Keywords: Caferli, Destination Image, Festivals, Rural Tourism.

Received: 01.07.2019

Accepted: 04.10.2019

Suggested Citation:

Ayyıldız, A. Y., Esen, Ö. and Ayyıldız, T. (2019). Festivals Effects on the Destination Image in Rural Tourism Regions: The Case of Kusadas1 Caferli, Journal of Turkish Tourism Research, 3(4): 1409-1420.

(C) 2019 Türk Turizm Araştırmaları Dergisi. 


\section{Gíriş}

Son yıllarda kırsal turizme olan ilgi giderek artmaktadır. İnsanların deniz, kum, güneş üçlemesi dışında farklı deneyimler yaşama isteğinden ortaya çıkarak oluşturulan ve alternatif turizm türlerinden biri haline gelen kırsal turizm, turizm sektöründe giderek önem kazanmaktadır. Şehir stresinden uzaklaşma, monoton hayatın dışına çıkma, doğal yaşamla iç içe yaşam geçirme isteğinden yola çıkarak oluşan bir ilgidir. Bu ilgiden hem üretici hem de tüketici olumlu ve olumsuz olarak etkilenmektedir.

Turizm rekreasyonel faaliyetler bütünüdür. Her geçen gün istek ve beklentilere daha fazla karşılık vererek gelişim gösteren bir sektördür. Bu gelişimin ülkeye ve bölgeye olan katkıları yadsınamaz. Deniz kıyısı dışında kırsal bölgelerde yapılan festivallerin çekicilik unsurları önemlidir.

Kırsal bölgelerde düzenlenen festivaller kırsal bölgelerin doğal, tarihi ve kültürel özelliklerini ön plana çıkararak dikkat çekilmesini sağlamaktadır. Belirli zaman aralıklarında düzenlenen temalı halk günleri olarak bilinen festivaller bölgenin bilinirliğine önemli ölçüde katkı sağlamaktadır. Kırsal alanlarda düzenlenen festivaller vasıtasıyla pek çok yerli ve yabancı ziyaretçi o bölgeyi ziyaret ederek tanıma imkanı bulmaktadır. Bu ziyaretin sonucunda bölgeden mutlu ayrılan ziyaretçiler ise o bölgeyi tekrar ziyaret etme eğilimi gösterebilmektedir. Bu sayede kırsal turizmin yapıldığı küçük yerleşim birimleri olan köylerin kalkınması ve destinasyon imajının oluşması da sağlanmış olacaktır. Destinasyon imajı güçlenmiş bir bölge, zaman içerisinde tanıtım ve pazarlama unsurlarına gerek kalmaksızın kendi kendini pazarlayabilme yetisine sahip olabilecektir. Bölgelerde yapılan festival isimleri sayesinde o bölgeler bilinir hale gelmektedir. Bu festivaller ulusal olabileceği gibi uluslararası da olabilir. Çeşme-Alaçatı' da yapılan "Ot Festivali", Fransa' daki "Cannes Film Festivali, Brezilya' daki "Rio Festivali", İspanya'da ki "Boğa Güreşleri Festivali", gibi örneklerde bulunan festivaller sayesinde destinasyonlar bilinir hale gelmektedir. Kırsal bölgelerde yapılan festivaller de kırsal bölgelerin adından bahsettirecek ve bölgenin destinasyon imajının geliştirilmesine katkı sağlayacaktır.

Bu çalışmada Caferli'de bulunan işletme sahipleriyle yapılan görüşmeler sonucunda kırsal bölgelerde yapılan festivallerin destinasyon imajına katkısı incelenmiştir. Aydın ilinin Kuşadası ilçesinde bulunan kırsal alanlar incelendiğinde geleneksel olarak düzenlediği festivalleriyle adını duyuran tek kırsal alan olması sebebiyle araştırma için Caferli seçilmiştir.

\section{LITERATÜR TARAMASI}

Kırsal turizm, turizm sektöründe gün geçtikçe değerlenen bir kavram haline gelmektedir. Kırsal turizmin ne olduğunu anlamak için kırsal alan kavramını anlamak gerekmektedir. Kırsal alan kavramının kırsal turizmin açılanmasında kullanılan temel bir kavram olması sebebiyle kırsal turizmi anlamlandırabilmek amacıyla tanımlanması gerekmektedir. Türkiye'de 1924 tarihli Köy Kanunu'na göre 20.000 'den daha az nüfusa sahip yerleşim birimleri kırsal alan olarak tanımlanmaktadır (Uçar, 2010: 101). Ülkemizde genellikle şehir merkezinin dışında kalan "köy" olarak adlandırılan küçük bölgelerde kırsal turizm yapılmaktadır.

Kırsal alan denilince akla ilk gelen tarım ve hayvancılık faaliyetleridir. Turizm bunlara sonradan dahil edilmiştir. Kırsal turizmin en kısa tanımı "kırsal alanlarda gerçekleştirilen turizm faaliyetleridir". Kırsal turizm denilince büyük şehirlerin yakınlarında bulunan tarihsel ve kültürel zenginliklere sahip köylerde hafta sonlarını kapsayan günübirlik yeme-içme, köy 
ziyaretleri, alışveriş, doğa yürüyüşleri ve sporlarını içeren rekreasyon faaliyetleri düşünülmektedir (Ongun, 2015: 47)

Türkiye kırsal turizme yönelik olan coğrafi, doğal ve tarihi bakımdan oldukça zengindir. Dört mevsimi bir arada yaşayan bir ülke olması ve kırsal turizm amaçlı kullanılabilecek birçok doğal güzelliği içerisinde barındırmasından dolayı kırsal turizme elverişli bir ülkedir (Özçatalbaş, 2006). Sahip olduğu dağlık alanlar, ormanlar, mera ve çayır alanlar hayvancılık ve yaylacılık imkanlarına sahip olmasından dolayı geçmişten beri birçok çeşitli tarımsal üretim yapılmaktadır. Günümüzde ise bu bölgelerin yeni bir turizm türü olan kırsal turizm amacıyla kullanıldığından söz edebiliriz. Ayrıca yöresel el sanatları, geleneksel köy faaliyetleri, cirit, deve, boğa güreşleri gibi geleneksel sporlar, yaylalar kırsal alanların yapıtaşlarıdır (Özdemir Yılmaz ve Kafa Gürol, 2012: 27).

Kırsal turizm belli bir dönem boyunca değil yılın 12 ayında da gerçekleştirilebilmektedir, iklimsel olaylardan etkilenmeyen bir alandır, bu nedenle turizm gelirleri için önemli bir turizm çeşididir. Dört mevsim boyunca uygulanabilmesi nedeniyle kırsal turizm bölgelerinde yapılabilecek etkinliklerin çeşidini de artırmaktadır. Festivaller de bu etkinlikler arasında yer almaktadır (Soykan, 2003: 2-4).

Dönemi, yapıldığı yer, konusu, katılımcı sayısı ve programı önceden belirlenmiş; sanat, bilim, kültür, ekonomik faaliyet, ürün veya belli bir temaya göre organize edilen tek seferlik ya da belirli zaman diliminde tekrar etmesi planlanan etkinlikler bütününe festival denir. Festivallerin amacı sadece ekonomik katkı sağlamak değil bireyler ve toplumlar arasında kültürel ve sosyal açıdan yakınlaşma sağlamaktır. Bu sayede farklı bireyler ve toplumlar arasında etkileşim sağlanarak kültür alışverişinin yaşanmasına da yardımcı olur (Dalgın vd., 2016: 1180)

Festivaller topluluk ve kutlama olaylarına odaklanmaktadır. Festivaller genellikle aynı coğrafya da yaşayan veya bölgesel ortaklığı bulunan bir grup insanın kendi içerisinde oluşturduğu bir kutlama temasıdır. Festivallerin diğer etkinliklerden farkı genellikle ev sahibi toplumun değerlerini yansıtıyor olmasıdır (Small, 2007).

Sanatsal etkinlikler, resmi kutlamalar, siyasi ve ticari etkinlikler içeren festivaller, özel bir fikri veya belirli yapımları tanıtmak için düzenlenir. Festival kelimesi aynı zamanda eşsiz bir kültürel değer veya yüksek katılımlı etkinlikler için de kullanılır. Festivaller geçmişte yerel halk tarafından yaratılmış ve organize edilmiş iken günümüzde ise yaygınlaştırılmış olaylar turizm yardımı ile daha çok insan hitap etmektedir. Festivaller dış dünya ile sınırların aşılmasının ötesinde yerel ve kültürel ilişkilerin de gelişimini sağlamaktadır (Uğuz ve Gacnik, 2015). Araştırmacılardan Getz (1991), Chacko ve Schaffer (1993), McKercher vd., (2006) festivallerin turizm üzerindeki etkilerini küresel çekicilikleri ile dile getirmiştir. Festivaller, her yıl gerçekleştiği yerlere binlerce turist çekmektedir. Çünkü festivaller, bu bölgelere seyahat etmeleri için turisti çağıran önemli etkinliklerdir. Ancak ziyaretçilerin festivallere farklı motivasyonlarla katılma eğilimi vardır (Uğuz ve Gacnik, 2015: 278-280). Bu motivasyonlar kişiden kişiye değişkenlik gösterebilmektedir.

Bireyler için de özel bir çekicilik unsuru olan etkinliklerden festivallerin turizmdeki önemi büyüktür. Birçok çeşidi olan festivaller genel olarak eğlence, kültürel paylaşım, sosyalleşme ve motivasyona sahip insan topluluklarının belirli bir bölgede dikkat çekerek festival yapılan destinasyona dikkat çekilmesini sağlamaktadır (Dalgın, Atak, ve Çeken, 2016: 1180). Ancak festivaller sadece turizm avantajları sağlamakla kalmamakta aynı zamanda içinde bulundukları toplulukların sosyal yapısının, topluluk kimliğinin ve aidiyet duygusunun gelişmesine de katkıda bulunabilmektedir (Small, 2007). 
Festivaller, turizm sezonunu uzatarak hükümetlere, restoran, otel, zanaatkar, eğlence merkezleri gibi yerel dükkanlardan mal ve hizmet alımı gerçekleştiren ziyaretçiler sayesinde yerel halk için gelir kaynağı yaratabilmektedir. Sağladığı ekonomik gelir sayesinde mevcut işletmeleri destekleyerek yeni girişimcilere de istihdam alanı yaratabilmektedir. Festival ziyaretçilerinin ihtiyaçlarına göre büyümek, yerel girişimciler ve bölge dışında güçlü bağlantılar kurma çalışmaları sayesinde de bölge gelişebilmektedir (O'Sullivan ve Jackson, 2002: 326-327). Festivaller ekonomik gelir kaynağı sağlamanın yanı sıra yapıldıkları bölgelerin tanıtımına da katkıda bulunmaktadır.

Festivallerin destinasyonların tanıtımında etkisinin bulunması, bu sebeple yapıldıkları bölgelere ziyaretçi çekmesi nedeniyle turistik talep artışındaki önemi büyüktür. Festival sebebiyle destinasyonu ziyaret eden turistler tekrar ziyaret etme potansiyeli gösterebilmektedir. Bir başka etkisi ise turistin konaklama süresini değiştirmesine sebep olabilmesidir. Bölgeden memnun kalan turistler planladıkları seyahat süresinin dışına çıkabilirler (Çoban ve Süer, 2018: 60)

Giritlioğlu, Olcay ve Özekici (2015) Türkiye'de düzenlenen festivallerin temalarına, düzenlenme zamanına ve düzenlendiği bölgelere göre sınıflandırılmasını araştırmışlardır. Araştırma sonucunda Türkiye'de bir yıl içinde farklı içeriğe sahip olan toplam 1254 festival düzenlendiği tespit edilmiş olup en fazla sayıda festivalin Marmara Bölgesinde ve en az sayıda festivalin Güney Doğu Anadolu Bölgesinde gerçekleştirildiği ortaya konulmuştur.

Birçok türü bulunan festivallerin son yıllarda sık çalışılan bir konu olduğu gözlenmektedir. Festivallerin kalitesi niteliklerine göre farklı boyut ve ifadelerle ölçülmektedir (Doğrul, Kandemir, ve Şahin, 2015: 74-75). Kırsal alanlarda yapılan festivallerde kırsal destinasyon imajına dikkat çekmeyi sağlamaktadır.

Destinasyon imajı, turistlerin varış yeri seçimini etkileyen en önemli faktörlerden biridir. Destinasyon imajı bireysel ve gruplar arasında farklı algılamaları ifade eder. Bu algıları bilissel, duyuşsal ve görsel boyutlar etkiler. Destinasyon imajı bu bileşenlerle zihinde bir imaj yaratmaktadır. Tüketicinin yorumu ve beklentileri, incelenen bu boyutlarla ilgilidir (Allameh vd., 2014: 193). Oluşan bu boyutlar sayesinde bir destinasyon hakkında olumlu veya olumsuz fikirler meydana gelmektedir. Meydana gelen bu fikirler sayesinde turistler o bölgeyi ziyaret ederek deneyim kazanmaktadır.

Bir destinasyona yönelik duygu ve düşünceler, turistlerin o bölgeyi deneyimlemeleri sonucunda oluşur. Deneyimlerinin sonuçları sosyo psikolojik ve seyahat çeşitlerine göre farklılık gösterebilmektedir. Bu deneyimi tecrübe etmeyen kişiler ise destinasyonu daha önce ziyaret etmiş kişiler veya destinasyona ait bilgilendirici turizm tanıtım faaliyetlerinden destinasyonla ilgili bilgilere erişerek fikir sahibi olabilmektedir (Cavlak ve Cop, 2018: 275).

Trauera ve Ryan (2005), geçmiş deneyimlerin ve bir bölgeye duyulan bağlılı̆̆ın ya da yakınlığın da olumlu bir destinasyon imajı geliştirmek açısından hedef kitleyi etkilemek konusunda pozitif katkı sağladığını tespit etmişlerdir. Enformasyon kaynakları ve geçmiş deneyimlere ek olarak kişilik özellikleri de algılanan imajı etkilemektedir.

Turistik destinasyon imajı hem potansiyel turistlerin karar alma davranışını hemde turist deneyimine ilişkin memnuniyeti etkilediği gözlemlendiğinden önemlidir. Varış yeri seçiminde kritik bir faktör olan destinasyon imajı bölgede turiste sunması gereken konularda temsili bir imge konumundadır (Jenkins, 1999:1-2). Bu sebeple destinasyon imajı oluşturmak ve ziyaretçilere sunmak ülkemizin hem tanıtımı hemde ekonomik bir kaynak oluşumu sağlaması yönünde oldukça önemli bir konudur. 
Çalışmada yer alan Caferli, gerçekleştirdiği festivaller sonucunda bir destinasyon imajı oluşturma aşamasında olan yerleşim yerlerinden biridir. Aydın ilinin Kuşadası ilçesine bağlı Caferli 2014 yılına kadar köy statüsündeyken Kuşadası Belediyesi'ne bağlanarak mahalle olmuştur. Caferli' de 2016'dan itibaren 3 adet işletme açılmıştır. Bu işletmelerden biri “N. Deniz Butik Otel'dir". 3 odalı küçük bir işletme olarak hizmet vermektedir. Aynı zamanda yine aynı işletme sahibine ait Nazlı Deniz Şale Restoranı bulunmaktadır. Diğeri "Bahçem Gözleme ve Kahvaltı Evi" 3. İşletme ise belediyeye bağlı olarak hizmet vermekte olan "Köy Kahvesi'dir"(Kuruoğlu, 2014:1).

\section{YÖNTEM}

Kırsal turizm bölgelerinde yapılan festivallerin destinasyon imajına etkisinin incelendiği bu çalışmada Caferli'de bulunan işletme sahiplerine yarı-yapılandırılmış görüşme tekniği uygulanmıştır. Açık uçlu soruların yer aldığı yarı-yapılandırılmış görüşme formu hazırlanarak, işletme sahipleri ile yüz yüze görüşmeler gerçekleştirilmiştir. Araştırmada veri toplama yöntemi olarak görüşme tekniği yönteminin kullanılmasının sebebi elde edilmek istenilen verilerin ölçekli sorularla elde edilmesinin mümkün olmaması ve araştırmaya konu olan işletme sayısının az olmasıdır. Yarı yapılandırılmış görüşme formu Metin Uçar'ın(2012) “Kırsal Turizmin SosyoEkonomik Yapıya Etkisi ve Fethiye Örneği" adlı çalışmasında kullandığı mülakat sorularından, Ayşe Nevin Sert'in(2017) "Yerel Halkın Festivallerin Başarı Faktörlerini Algılamalarına Yönelik Bir Çalışma: Beypazarı Örneği" adlı çalışmasında kullandığı anket sorularından ve Utku Ongun'un(2015) “Kırsal Turizmin Kırsal Kalkınmaya Etkisi: Şirince Örneği” başlıklı doktora tez çalışmasında kullandığı mülakat sorularından derlenerek hazırlanmıştır.

Görüşme formu iki kısımdan oluşmaktadır. İlk kısımda katılımcıların yaş, cinsiyet, eğitim durumu, medeni durum olmak üzere demografik özelliklerinin yer aldığı sorulara yer verilmiştir. İkinci kısımda ise, katılımcılara Caferli'de hangi iş ile uğraştıkları, Caferli'nin kırsal turizmin gelişmesi açısından uygun olup olmadığı hakkındaki düşünceleri, yerli turistin mi yabancı turistin mi Caferli'ye daha çok geldiği, Caferli'nin tanıtım ve reklamının yeterli düzeyde yapılıp yapılmadığı ile ilgili düşünceleri, Caferli'ye özgü ürünlerin neler olduğu, Caferli'nin en önemli alt yapı ve üst yapı sorunlarının neler olduğu, Caferli'ye ulaşım olanakları, Caferli'de yapılan festivaller hakkındaki düşünceleri, festivallerin Caferli'ye olumlu, olumsuz katkıları, festivallerin Caferli'nin doğal güzelliklerine ve tarihi dokusuna, çevre kirliliğine etkisi, yerel yönetimlerin Caferli'de yapılan festivallere destekleri, festivallerin yörenin tanınırlı̆̆ına etkisi, Caferli'nin daha iyi bir imaja sahip olması için yapılması gerekenlere yönelik sorulara yer verilmiştir.

Araştırma verilerinin toplanması amacıyla 24 Mayıs 2019 tarihinde Caferli'de, işletme sahipleri ile önceden randevu alınarak yüz yüze görüşme gerçekleştirilmiştir. Caferli'de toplam üç adet işletme bulunmaktadır. İşletme sahiplerine soru formunda yer alan sorular yöneltilerek görüşmeler gerçekleştirilmiştir. Görüşme sırasında verilen cevaplar soru formuna yazılarak ve ayrıca ses kayıt cihazı ile kayıt sağlanarak araştırma bulguları elde edilmiştir. Araştırma süreci sonrasında elde edilen veriler betimsel analize tabi tutulmuştur.

\section{BULGULAR}

Mülakatın ilk bölümünde katılımcıların demografik özelliklerini belirlemeye yönelik sorular yöneltilmiştir. Caferli'de işletme sahipleri ile yapılan görüşmeler sonucunda elde edilen demografik bilgiler tablo 1'de yer almaktadır. 
Tablo 1. Katılımcıların Demografik Özellikleri

\begin{tabular}{|l|l|l|l|l|}
\hline Katılımc1 & Yaş & Cinsiyet & Medeni Durum & Ĕgitim Durumu \\
\hline 1 & 57 & Kadın & Bekar & Yüksek Lisans \\
\hline 2 & 59 & Erkek & Evli & İlköğretim \\
\hline 3 & 68 & Erkek & Dul & İlköğretim \\
\hline
\end{tabular}

Tablo 2'de Caferli'de yer alan işletmelerin türü ve hizmet verdikleri süre yer almaktadır.

Tablo 2. Katılımcıların Meslek Durumlarına ve İşletmenin Hizmet Verme Süresine Göre Dağılımı

\begin{tabular}{|l|c|}
\hline Meslek & İşletmenin Hizmet Verme Süresi \\
\hline Otel ve Restoran İşletmecisi & 20 \\
\hline Kahvehane İşletmecisi & 45 \\
\hline Gözleme ve Kahvaltı Salonu İşletmecisi /Çiftçi & 3 \\
\hline
\end{tabular}

Çalışmada Caferli'de yer alan işletme sahipleri ile yapılan görüşmelerde, katılımcılara görüşme formunda yer alan sorular yöneltilmiştir. Daha sonra katılımcıların vermiş oldukları cevaplar tek tek incelenerek bu bölüme aktarılmıştır.

Yapılan görüşmelerde katılımcılara ilk olarak "Caferli'nin kırsal turizmin gelişmesi açısından uygun bir yer olduğunu düşünüyor musunuz?" şeklinde bir soru yöneltilmiştir. Katılımcilar bu soruya olumlu yanıtlar vermiştir. Caferli tarıma elverişli olduğundan tam bir kırsal bölge olduğu, doğası ile ön plana çıktı̆̆ı, ikliminin güzel olduğu düşünülüyor. Katılımcılardan birinin ifadesine göre "Caferli'de her şey doğal, meyve, sebze tazecik, havası güzel, yaşamak için elverişli".

"Yerli turist mi yoksa yabancı turist mi Caferli'ye daha çok gelmektedir?" sorusu yöneltilen katılımcılar genel olarak gelenlerin yerli turist olduğunu yabancı turistin az sayıda geldiğini ifade etmişlerdir. Katılımcılardan otel ve restoran sahibi, Caferli'nin hem yabancı hem de yerli turizme hitap eden bir yer olduğunu fakat tanıtımın yetersiz olmasından dolayı daha çok sosyal medya aracılığıyla yerli turiste ulaşılabildiğini söylemiştir. Yerli turistin ise, çoğunlukla hafta sonları ve resmi tatillerde 1-2 günlük konaklama yaptı̆̆ını ifade ederek, özellikle yerli ve yabancı turistler açısından günübirlik tur programları düzenlenirse, bir turistin Caferli'de kalması için yapılacak aktiviteler çeşitlendirilirse gelen turistlerin daha fazla vakit geçirip, konaklama yapacağını belirtmiştir.

“Caferli'nin yeterli düzeyde tanıtım ve reklamının yapıldığını düşünüyor musunuz? Yapılmıyorsa neler yapılabilir?" sorusuna katılımcılardan farklı cevaplar alınmıştır. Katılımclardan ilki “...hayır yapılmıyor. Köyümüzde internet altyapı problemi sebebiyle sosyal medyada bile yeterince tanıtılamıyor. Yurtdışına tanıtımına ağıılık verilmeli. Caferli doğallığı ve organikliği ile ön planda olan bir yer. Tanıtım için Kuşadası Belediyesi ve Kültür Turizm Bakanlığı'nın desteği olmalı bu destek ile çok daha farklı yenilikler sağlanabilir." şeklinde cevaplamıştır. Diğer katılımcı 4-5 senedir festivaller sayesinde tanıtımın yapıldığını, festivallerin yörenin tanıtımına büyük katkı sağladığını söylerken, son katılımcı ise “...köyümüz son 2-3 yıldır muhtarımız tarafindan yönetilen Dayanışma ve Yardımlaşma Derneği sayesinde tanınıyor, sosyal medya ile daha fazla tanıtımlar yapılmalı, etkinlikler düzenlenmeli." diyerek yanıtlamıştır. 
"Caferli'ye özgü ürünler nelerdir? Bu ürünler yeterince tanınıor mu?" sorusuna katılımcıların tümü şeftali, zeytin, zeytinyağı, narenciye gibi ürünlerin olduğu yanıtını vermişlerdir. Bu ürünlerin Kuşadası ve çevresinde kurulan pazarlara gidilerek satışı sağlanmaktadır. Festival dönemlerinde ise yörede stantlar kurularak gelen ziyaretçilere sunumu yapılmaktadır. Ayrıca Kuşadası'nda her yıl düzenlenen Zeytin Festivali'nde Caferli Standı açılarak, orda da ürünlerin, özellikle zeytinyağının, tanıtım ve satış yapılmaktadır. "Bu bölgenin en kaliteli şeftalisi Caferli'de yetişiyor, tanıtım yetersiz olduğu için pek kimse bunu bilmiyor, ama daha etkili tanıtım yapılırsa Caferli şeftalisi bir numara olur.

"Caferli'nin en önemli sorunları nelerdir?" sorusunun ortak cevabı internet altyapısının bulunmaması ve ulaşım problemidir. Katılımcılardan biri bu soruya şu şekilde cevap vermiştir; “... altyapı, yol, ulaşım hiç yok. Özellikle internet Caferli'nin büyük problemi, festivaller köyün değeri arttırdığ için şu an göç durdu. Fakat nüfus olarak az. Burada okul yok, çocuklar dışarıda akrabalarının yanında eğitim alıyor. İlköğretim düzeyinde eğitim için bile başka şehirlere gitmek zorundalar, ulaşım olmadığı için gidip gelme yapamıyorlar. Gelen turistlere konaklama imkanı veremiyoruz. N. Deniz Butik otel dışında bir alternatif maalesef yok, orası da 3 odalı olduğu için grup olarak gelen ziyaretçiler için oldukça yetersiz kalıyor. Ancak bireysel ziyaretler için uygun. Diğer katılımcı ise “... ulaşım en büyük problemimiz, işsizlik oranı az çünkü genç nüfus sayısı da az. Sağllk hizmetini Davutlar ilçesinden alıyoruz. Haftada 1 gün hemşire gelerek tansiyon ölçüyor. Bunun dışında fazla bir şey yapılmıyor. Belediye'den ulaşım sağlanabilmesi için söz aldık ama sonucunu bekliyoruz." şeklinde yanıtlamıştır.

"Caferli'ye ulaşım olanakları sizce yeterli düzeyde midir?" sorusuna katılımcılar yetersiz, ulaşım yok cevaplarını vermişlerdir. Bir katılımcı "...dolmuş şoförleri buraya gelmek istemiyor. En azından günde 3 kez seferler düzenlenebilir." diyerek yanıt vermiştir. Başka bir katılımcı "... yeterli değil hatta toplu taşıma hiç yok. Az da olsa günlük seferler olmalı. Muhtarımız, Kuşadası Belediye Başkanı ile iletişime geçiyor fakat şoförler katılım sağlamıyor. Ulaşım olmaması yapılabilecek etkinliklerin de önüne geçiyor. Daha önce Kuşadası Belediyesi festival ve çalıştay yapıldığı dönemlerde araç tahsis etmişti, ama düzenli dolmuş seferleri olsa daha çok turist gelir".

"Caferli' de festival yapılmasından memnun musunuz?" sorusuna tüm katılımcılar evet cevabını vermiştir. Güz ve bahar dönemlerinde olmak üzere yılda 2 festivalin gerçekleştiğini festivaller sayesinde Caferli'nin tanınırlığının arttığını ve ekonomik anlamda kalkınma sağladıklarını belirtmişlerdir. Başka katılımonın yorumu ise şu şekildedir; "... burada 9-16 Haziran tarihleri arasında çiçek festivali ve güz dönemine doğru güz ve çevre festivali yapılır. Bu festivallerden memnunuz, insanlar köyümüze geliyor, ekonomik olarak bizde faydalanıyoruz, Fakat bizim asıl festival düşüncemiz pilav ve keşkek festivali idi. Onu henüz yapamadı ama bu festivallerin yapılmasından da memnunuz." cevabını vermiştir. Diğer katılımcı "...2 festival oluyor. Muhtarlık Caferli Güzelleştirme ve Dayanışma Derneğinin düzenlediği güz ve çevre festivalini kabul etmiyor, destek vermiyor. Muhtarlık 5 yıldır çiçek festivali yapıyor. Bu festivale sanatçılar geliyor, çiçek satılıyor. Yaklaşık 2000-2500 kişinin katılım gösterdiği güz ve çevre festivalinde ise çevreyle ilgili belgesel gösterimi, konser, gözleme satışı, resim yarışması gibi faaliyetler yapılıyor. İki gün süren bu festivalde kullanılacak masa, sandalye, ulaşım hizmeti ve maddi yardım gibi imkanları Kuşadası belediyesi destekliyor.

"Festivallerin Caferli'ye olumlu katkıları (faydaları) nelerdir?" sorusuna katılımcların ortak yorumu Caferli'ye ekonomik katkı sağlayarak, refah seviyesini yükseltmesi ve tanıtımının yapılması olduğu yönündedir. "Festivallere olan ilgi sayesinde burayı bir kere ziyaret edenler, daha sonra tekrar gelebiliyor. Caferli adı festival sayesinde duyuluyor. "Festivallerin Caferli'ye olumsuz katkıları (zararları) nelerdir ?" sorusunun ortak cevabı ise, zararı yok şeklindedir. Festival döneminde yaşanılan olumsuz bir olay bulunmadığını belirtmişlerdir. Fakat katılımcılardan biri festival zamanı oluşan yoğun araç trafiği ve Caferli'de otopark bulunmamasından dolayı, araç trafiğinin yol boyunca uzadığını ifade etmiştir. 
"Festivallerin Caferli'nin doğal güzelliklerinin ve tarihi dokusunun bozulmasına, çevre kirliliğine etkisi var mıdır?" sorusuna katılımcılar çok fazla çöp olmadığını çünkü etkinlik sürecince plastik ve naylon kullanılmadığını belirtmişlerdir. Güz ve Çevre Festivali tanıtım afişlerinde katılımcıların özenli olmasını rica ettikleri ve kesinlikle plastik, naylon, çevreye zarar veren ambalaj kullanmamaları gerektiği ile ilgili bir not bulunmaktadır. Festival'de içecekler cam şişelerde satılıyor, bez çantalar ve kese kağıtları ürün satışlarında paketleme için kullanılıyor, zeytinler cam şişselerde sunuluyor, yiyecek servislerinde kağıt tabaklar kullanllıyor. Yerel halk buna öncülük ederek, özen gösterdiği için katılımcılarında aynı hassasiyeti gösteriyor. Plastik beyaz sandalyeleri bile kumaş örtüyle kaplayarak, festival süresince görüntüye dikkat etmeye çalışıyoruz. Maddi imkanımız olsa plastik hiç malzeme kullanmayıp, daha sağlıklı ahşap, masa, sandalye kullanırız.

"Yerel yönetimler festivallere yeterli düzeyde destek veriyorlar mı? Yerel yönetimlerden beklentileriniz nelerdir?" sorusuna katılımcılar 2019 yılına kadar destek verildiğini sonrasında yerel seçimler gerçekleştiği için yeni durum hakkında fikirleri olmadığını belirtmişlerdir. Yerel yönetimlerden en çok ulaşım konusunda destek bekledikleri, internet sorununa çözüm bulmalarını istediklerini, festival boyunca yapılan etkinlikler için masa, sandalye, sahne, afiş, reklam, sosyal medya desteği ve maddi konularda destekler beklemektedirler.

"Festivaller sayesinde yörenin tanınırlığı artmakta mıdır? Caferli'nin imajını festivaller olumlu yönde etkilemekte midir?" sorusuna katılımcılar, yörenin tanınırlığının arttığını, destinasyon imajına olumlu katkı sağladığını ifade etmişlerdir. Caferli'ye yerleşen ve burada işletmecilik yapan Türkiye ve Avrupa güzeli Nazlı Deniz Kuruoğlu'nun ve dansçı Burçin Orhon'unun da burada yaşaması medyanın ilgisini çekmektedir. Caferli Güzelleştirme ve Dayanışma Derneği başkanı olarak Güz ve Çevre festivalini düzenleyen Nazlı Deniz Kuruoğlu'nun medyatik ismi festivalin daha fazla ses getirmesine katkı sağlamaktadır.

"Caferli'nin daha iyi bir konuma gelmesi ve daha iyi bir imaja sahip olması için neler yapılabilir, sizin tavsiyeleriniz nelerdir?" sorusuna katılımclardan biri "Mevcut doğal güzelliği ve dokuyu bozmadan, festivallerin devam etmesi gerekmektedir" diyerek cevap vermiştir. Ayrıca, bundan sonra yapılacak evlerin taş ev şeklinde, tek renk yapılarak yörenin tarihi dokusunun ve mimari yapısının korunması gerektiğinin önemi vurgulanmıştır. Güz ve Çevre Festivali, Çiçek Festivali dışında kültür sanat ve müzik festivali de yapılabileceği önerileri bulunmaktadır. Özellikle ileride yapılabilecek dans ve sanat festivali için, Caferli'de yaşayan işletmecilerden biriyle görüşme yapılırken orada bulunan Burçin Orhon' da destek vermeye hazır olduğunu bildirmiştir.

Festivaller dışında kalan zamanlarda da daha çok yerli ve yabancı turist gelmesini istedikleri yönünde beklentileri bulunmaktadır. Bölgeye yakın yerlerde yapılan günlük turların, tur otobüslerinin köye girmesi sağlanmalı ve molaya teşvik edilmesi gerektiği vurgulanmaktadır. Daha çok turist gelmesi durumunda mevcut konaklama imkanı az olduğu için, yeni butik otellerin açılması gündeme gelebilir.

\section{SONUÇ VE ÖNERİLER}

Kırsal turizm bölgelerinde yapılan festivallerin destinasyon imajına etkilerinin araştırıldığ çalışmada Caferli'de hizmet veren toplam üç işletme vardır. İşletme sahipleriyle yapılan görüşmelerin sonucunda festivallerin Caferli'nin destinasyon imajına olumlu etkilerinin olduğu ortaya çıkmıştır. Kırsal turizm bölgesi olan Caferli'de senede iki defa olmak üzere düzenlenen Çiçek Festivali ve Güz ve Çevre Festivali'nin bölgeye turist çekerek Caferli'nin kalkınmasına 
katkı sağladığı sonucuna ulaşılmıştır. Caferli'nin uygun iklim koşulları, tarıma elverişli olması ve öne çıkan doğal güzellikleriyle tam bir kırsal turizm destinasyonu olduğu düşünülmektedir.

Caferli'de yapılan bu festivallerde çevreyi korumaya karşıda oldukça duyarlı davranıldığ gözlemlenmiştir. Festival süresince köylülerin kendi ürünleri olan zeytin, zeytinyağı, şeftali, narenciye, yöresel yemekleri stantlarda satışa sunduğu, festivallerde ürün satışlarında, plastik ve naylon kullanılmadığı, bunun yerine cam şişe, bez ve kese kağıdı, kağıt tabak gibi geri dönüşümü sağlanabilen maddelerin tercih edildiği ortaya konmuştur. Bu sayede sürdürülebilir turizme de katkıda bulunulduğu anlaşılmıştır. Caferli halkı bu konuda oldukça bilinçli davrandığından dolayı ve festival afişlerinde bu durum belirtildiği için gelen ziyaretçilerin de duyarlılığ sağlanmıştır. Kırsal turizm her mevsimde yapılabilen bir turizm türü olduğu için Caferli'de yapılabilecek etkinliklerin artmasıyla Caferli'nin destinasyon imajı güçlendirilebilir. Fakat küçük bir yerleşim birimi olması nedeniyle tarihi dokusunun ve kültürel yapısının korunması da önem arz etmektedir. Festivallerin Caferli'ye ekonomik katkı sağlayarak, Caferli'nin refah seviyesini yükseltmesi ve tanıtımının yapılması destinasyon imajına katkı sağlamıştır.

Caferli hem yabancı hem de yerli turizme hitap eden kırsal turizm destinasyonu olmasından dolayı daha fazla sosyal medya reklamlarıyla daha büyük kitlelerin ziyareti sağlanabilir. Ancak internet altyapısı buna henüz olanak vermemektedir. Yerel yönetimlerin desteğiyle adından daha fazla söz ettirebilen bir kırsal turizm bölgesi haline getirilebilir.

Kırsal turizm bölgelerinde festivallerin destinasyon imajına etkisinin araştırıldığı bu çalışmada Caferli' de kırsal turizmin ekonomik etkilerinin artması ve buna bağlı olarak bölgesel kalkınmaya olan etkisinin çoğalması ve destinasyon imajına olumlu yönde katkı sağlayabilmesi için şu çalışmaların yapılmasını önerilmektedir.

-Yerel halk kırsal turizm konusunda bilinçlendirilmeli ve halkın çevre bilinci geliştirilmelidir.

-Caferli'nin alt yapı ve üst yapı sorunları çözülmeli, bu konuda yerel yönetimler destek vermelidir.

-Özellikle daha etkili tanıtım yapılması için internet probleminin en kısa sürede çözülmelidir.

-Yerel halk festivallerin etkileri konusunda bilgilendirilmelidir.

-Festivale gelen ziyaretçilerin çevreyi temiz tutmalarına yönelik bilinçlendirici ve uyarıcı tabelaların yer alması sağlanmalıdır.

-Kırsal alanların tanıtımında ve yöreye turistik talebin çekilmesinde seyahat acentalarının rolü fazladır. Kuşadası ve çevresinde bulunan seyahat acentalarının kültür turları kapsamında Caferli'yi programlarına dahil etmeleri, Caferli'ye günü birlik geziler düzenlemeleri için seyahat acentalarıyla işbirliği yapılmalıdır.

-Festival süresince etkinliklerde çalışanların büyük çoğunluğunu köy halkı oluşturmaktadır. Turistlerin beklentilerin daha iyi karşılanması ve sunulan turistik hizmetin kalitesi açısından yöre halkına eğitim verilmesi önemlidir.

-Festivallerin gelişimiyle ilgili planlama yapılırken yörenin taşıma kapasitesi dikkate alınmalıdır. Taşıma kapasitesi dikkate alınmadığında sosyokültürel olumsuzluklar baş göstereceği gibi çevre ve doğal kaynaklar üzerinde de tahribat söz konusu olacaktır. Bütün bu olumsuzluklar da festivallerin sürdürülebilirliğini imkansız hale getirebilmektedir.

-Caferli'yi ziyaret eden turistlerin konaklamaları için gerekli imkanlar artırılmalıdır.

Sonuç olarak Caferli'de düzenlenen festivaller Caferli'nin destinasyon imajına olumlu yönde katkı sağlayarak yörenin adını duyurmada etkili olmaktadır. Yapılan bu araştırmanın ileride yapılacak olan kırsal turizm ve festivallerin konusunda yapılacak araştırmalara kaynaklık edeceği düşünülmektedir. 


\section{KAYNAKÇA}

Allameh, S. M., Pool, J. K., Asadi, H., and Salehzadeh, R. (2014). Factors Influencing Sport Tourists' Revisit Intentions. Asia Pacific Journal of Marketing and Logistics, 27: 193.

Cavlak, N., ve Cop, R. (2018). Algılanan Destinasyon İmajı: Gelibolu Yarımadası Tarihi Milli Parkı'nı Ziyaret Eden Turistler Üzerine Bir Araştırma . Akademik Sosyal Araştırmalar Dergisi, 6(84): 275.

Chacko, H., and Schaffer, J. (1993). The Evolution of a Festival: Creole Christmas in New Orleans. Tourism Management, 14(6): 475-482.

Çoban, M., ve Süer, S. (2018). Destinasyon Markalaşmasında Festival Turizminin Rolü: Alaçatı Ot Festivali Üzerine Bir Çalışma. Uluslararası Güncel Turizm Araştırmalaıı Dergisi, 2(1): 60.

Dalgın, T., Atak, O., ve Çeken, H. (2016, Aralık). Festivallerin Bir Kırsal Turizm Çekiciliği Olarak Önemi. Uluslararası Sosyal Araştırmalar Dergisi, 9(47), 1180.

Doğrul, Ü., Kandemir, A., ve Şahin, A. (2015). Festival Kalitesinin Ziyaretçilerin Algıladıkları Değer, Tatmin ve Sadakat Üzerine Etkisi: Mersin Uluslararası Narenciye Festivali Üzerine Bir Uygulama. Çă̆ Üniversitesi Sosyal Bilimler Dergisi, 12(1): 74-75.

Getz, D. (1991). Festivals, Special Events, and Tourism. New York: Van Nostrand Reinhold.

Giritlioğlu, İ., Olcay, A., ve Özekici, Y. K. (2015). Bir Turizm Çeşitliliği Olarak Festival Etkinliklerinin Sınıflandırılması: Türkiye Üzerine Bir Değerlendirme. Ordu Üniversitesi Sosyal Bilimler Enstitüsü Dergisi, 5(13): 315-316.

Jenkins, O. H. (1999). Understanding and Measuring Tourist Destination Images. International Journal Of Tourism Research: 1-2.

Kuruoğlu, N.D. Kuşadası Caferli Güzelleştirme ve Dayanışma Derneği Kitapçı̆̆ı. (2014). Caferli Mahallesi Projesi. Aydın.

McKercher, B., Wan, S. M., and Tony, S. M. (2006). Are Short Duration Cultural Festivals Tourist Attractions? Journal of Sustainable Tourism, 14(1): 55-66.

Ongun, U. (2015). Kırsal Turizmin Kırsal Katkınmaya Etkisi: Şirince Örneği. Sosyal Bilimler Enstitüsü İktisat Anabilim Dalı Doktora Tezi. Isparta.

O'Sullivan, D., and Jackson, M. J. (2002). Festival Tourism: A Contributor to Sustainable. Journal of Sustainable Tourism, 10(4): 326-327.

Özçatalbaş, O. (2006). Türkiye'de Kırsal Turizm, TMMOB, Turizm Mimarlık Sempozyumu Bildiri Kitabi, Antalya. ss: 7-8.

Özdemir Yılmaz, G., and Kafa Gürol, N. (2012). Balıkesir İlinin Kırsal Turizm Potansiyelinin Değerlendirilmesi. KMÜ Sosyal ve Ekonomik Araştırmalar Dergisi, 23(14): 27.

Small, K. E. (2007). Understanding the Social Impacts of Festivals on Communities. A thesis submitted to the University of Western Sydney. Australia.

Soykan, F. (2003). Kırsal Turizm ve Türkiye Turizmi İçin Önemi. Ege Coğrafya Dergisi, 12(1): 2-4.

Trauer, B., and Ryan, C. (2005). Destination image, romance and place experience - An application of intimacy theory in tourism. Tourism Management, 26(1): 485-491. 
Uçar, M. (2010). Kırsal Turizmin Sosyo-Ekonomik Yapıya Etkisi ve Fethiye Örneği. Muğla Üniversitesi Sosyal Bilimler Enstitüsü Turizm İşletmeciliği Anabilim Dalı Yüksek Lisans Tezi. Muğla.

Uğuz, S. Ç., and Gacnik, A. (2015). Festivals As Cultural Attractions In Tourism: Case of Slovenia. Tourism, Environment and Sustainability: 285-287. 